\title{
INSTC (International North South Transport Corridor) connecting Eurasia and India
}

\author{
Shoaib Khan ${ }^{1}$
}

\begin{abstract}
The ongoing developments in the creation of North-South transport routes linking markets in South Asia with Europe via Iran and Russia have been less noted. The three thousand years old South Asian relations with Central Asia comprising the old silk route which was the trading backbone of the two regions covering around 7000 miles which connects the regions of China, Central Asia, Northern India the Parthian, the Roman Empire. The significance of INSTC cannot be underplayed; however, what has experts concerned is Iran seizing the opportunities brought on by its geographical position and turning such opportunities into competitive advantages.
\end{abstract}

Key Words: Central Asia, INSTC, Russia, China, Turkey, Iran, India.

\section{The Importance of Corridor}

The United States along with the European Union during the previous five years have emphasized the important role of countries of the Caucasus and Central Asia in the development of East-West transportation and energy

\footnotetext{
${ }^{1}$ Visiting Faculty, Centre for Central Eurasian Studies, University of Mumbai, President, ALFAAZ Education and Cultural Society, Mumbai, Lecturer, Mahim Social Workers College, Mumbai.

E Mail: shoaibk_92in@yahoo.com

DOI: 10.17932/EJOSS.2021.023/ejoss_v01i1003
} 
routes, linking Central and South Asia with Europe. The ongoing developments in the creation of North-South transport routes linking markets in South Asia with Europe via Iran and Russia have been less noted. There has been a large focus on weapons and technology transfers from Russia to Iran in recent analysis of relations between the two countries, the nascent North-South transport corridor signals an attempt to restore the conventional commodities trade between South Asia and Europe which is historical. The common interest of regional countries is also being demonstrated in this project to multiply the number of trade route options that extend north and south, as well as east and west ${ }^{1}$.

The interest of regional and extra regional powers has always been drawn by Central Asia because of its important geographical location connecting Europe and Asia. In the region, the presence of rich natural resources is another important reason to be in limelight for the major world powers. The historical Central Asia and South Asia relations which is economically and geopolitically linking the two regions. The three thousand years old South Asian relations with Central Asia comprising the old silk route which was the trading backbone of the two regions covering around 7000 miles which connects the regions of China, Central Asia, Northern India the Parthian, the Roman Empire. Recently Central Asia has drawn attention of major world powers to control the natural resources untapped in the area ${ }^{2}$.

The Indian Ocean and Persian Gulf to the Caspian Sea via Iran is presently being linked by INSTC route, and onward to northern Europe via St. Petersburg in Russia. The INSTC proposed movement of goods from 
Mumbai to Bandar Abbas in Iran by sea, from Bandar Abbas by road, and then from Bandar-e-Anzali to Astrakhan a Caspian port in the Russian Federation through Caspian Sea, and after that from Astrakhan to other regions of the Russian Federation and further to Europe by Russian railways ${ }^{3}$.

It is for the connectivity initiative to succeed, it would be prudent to take advantage of the existing transport initiatives in the Central Asian region. Towards Europe the BSEC is leaning heavily and the recent Ashgabat Agreement, which is more Central Asia-centric and are two most important.

The communication of Turkey with the Indian Ministry of Road and Transport according to many publications that Ankara is ready to provide information on linking the INSTC secretariat to the BSEC. There are however less details on its entails. Turkey, Russia and Ukraine among its 12 Eurasian members are included in the BSEC has seen limited progress in terms of initiatives implemented as a number of issues divide its members, making cooperation difficult. The European Union-supported Black Sea Ring Highway (BSRH) is one notable progress area.

The project as stated by the Turkish agency Anadolu is almost completed except some parts in the northern and western regions of the Black Sea and the Georgian section. On creating a BSEC certificate for trucks traveling along the highway the BSEC has also moved forward. Iran's ageing truck fleet as a result of decades of sanctions however is not authorized to drive on the roads of Europe as its trucks do not meet modern road standards according to Prof. Bahram Amirahmadian of University of 
Tehran. Upgrading its fleet to facilitate the BSRH to be utilised by Iran and setting up a mechanism assisting the issuing of the BSEC certificate to allow for trucks carrying consignments within Eurasia seemingly which for INSTC-BSEC cooperation would be a noteworthy goal ${ }^{4}$.

International North-South Transport Corridor (INSTC) as decided by Russia, Iran and India, a multimodal network of sea, rail and road routes between India, Iran, Central Asia and Russia. The new configurations undergoing in the broader politics that may put to question the project's prospects, and the evolving security situation demands continuous appraisal, it is time that the economics of INSTC initiative be refocussed on discussion. To evaluate this is an easier factor which will determine ground implementation as well as the corridor's present and potential scope along with it is also the ideal angle with which to pursue the initiative. The commercial advantages of a transport corridor have been examined by analysts and factors discussed that, if taken into consideration, strengthen INSTC's economic case. The potential economic merits of the corridor against the broader geopolitics of the region should be taken into account ${ }^{5}$.

The three founding members, Russia Iran and India, have agreed in 2000 and later it was ratified in the year 2002, the original multimodal route from Mumbai to Bandar Abbas and Bandar-e-Anzali the Iranian ports, following which across the Caspian Sea to Astrakhan, Moscow and St. Petersburg with sanctions on Iran had not seen much traction. The INSTC project recently has moved forward with Tehran back in the international 
fold and the 2016 agreement on Chabahar port which would likely be tapped as a second, or alternative, to the Bandar Abbas port.

The regional project has been joined by countries subsequently, in particular Azerbaijan, have been eager to connect to the INSTC and are pursuing projects that seek to diversify the original route. An alternate route pointed in a dry run conducted in 2014 using Azerbaijan's capital, Baku, as a transit point between Iran and Russia. In both Iran and Azerbaijan too, trial runs were conducted in August 2016. Goods will arrive in Russia through Azerbaijan via trains and trucks after being shipped to Bandar Abbas the southern Iranian port, avoiding the need to be shipped across the Caspian Sea as planned initially. Baku is being developed as a transport hub ${ }^{6}$.

The progress on the route was slow since the agreement was signed in 2002. A meeting in New Delhi on $18^{\text {th }}$ January, 2012 discussed the various modalities to take the project forward. Support were sought from other Central Asian nations and now the group has been expanded.

Iran, Russia, Azerbaijan, Kazakhstan, Armenia, Belarus, Tajikistan, Kyrgyzstan, Oman, Syria, Turkey, Ukraine, India are the current members along with Bulgaria as observer. A formal membership has not been allotted to Turkmenistan but is likely to have road connectivity to the corridor. There have been heavy involvement of Azerbaijan and Armenia in the project with both countries building new train lines and roads to complete the missing links in the INSTC ${ }^{7}$. 


\section{The Connectivity and Its Eurasian Integration}

The International North-South Transport Corridor (INSTC) has great potential for improving Iran's economic and political standing. The significance of INSTC cannot be underplayed; however, what has experts concerned is Iran seizing the opportunities brought on by its geographical position and turning such opportunities into competitive advantages.

Currently, besides North-South and East-West corridors, 10 other domestic corridors exist inside Iran, connecting different parts of the country together and with neighbouring countries. The existing infrastructure in the southern ports of Iran makes INSTC the best itinerary for expanding transit. The development project carried out in the Shahid Beheshti Port of Chabahar and its proximity to Central Asia and CIS countries has created eagerness on the part of India and Russia to employ this corridor for their transit purposes.

INSTC is estimated to reduce transit time and expenses by respectively 30 and 25 percent when compared with the traditional transit route between Mumbai Port and the Baltic Sea which crosses through the Bab-elMandeb, the Suez Canal and the Strait of Gibraltar. The INSTC route passes through Mumbai, Indian Ocean, the Persian Gulf, Anzali Port, Astrakhan Port and Moscow to reach Northern and Eastern Europe ${ }^{8}$.

Those countries which are already members of INSTC including the ones waiting to become members, are starting to realise that they cannot afford to deal with the aforesaid agenda at a later stage, considering the realities of geopolitics which changing at a rapid speed and emerging waves of 
Euro-Asian integration. An endeavour to that right away, not just among member states but crucially also with European partners, will increase the strength and utility of the corridor in the process. The economic interests of respective countries will be benefitted as well as the collective interests of the Euro-Asian community.

India might find itself walking on eggshells as it tries to maintain a delicate balance between its set of close allies and trading partners - the US, UK, Canada, Norway with the EU as well as Russia and Iran on other. The position that it could use to play as a leadership role in striking out a multiparty agreement for establishing rail, road and seaway connects it the Bothnian Corridors along with the Arctic, as well as to the North SeaBaltic, Scandinavian-Mediterranean and Baltic-Adriatic Corridors, through the INSTC.

It would also be in the interest of the Baltic, Nordic and Arctic states to look out for new possibilities for facilitating Europe-Asia trade, so as to have the options of foreign investments available and remain open to the massive infrastructure development initiatives backed by non-Baltic, nonNordic and non-Arctic states while avoiding getting locked up in any one scheme, and ensure balance of power in the Baltic, Nordic and Arctic regions ${ }^{9}$.

The ancient world cultures and its re-emergence is becoming the hallmark of the twenty-first century. China and India both have outgrown the term 'emerging market', in the decades of 2010s establishing themselves as movers and shakers in their own right. The transcontinental links recreated by the belt and road initiative that have criss-crossed Eurasia since 
antiquity, connecting the Roman, Persian, and Chinese empires and all the lands in between.

The new North-South corridors, linking Russia and South Asia and, here as well, all the lands in between are the emerging parallel development simultaneously. Though present-day India is still unsure as to whether her future lies with the rimlands of the Indo-Pacific or with the heartlands in Central Asia, there is little doubt that other than the factors historically and politically, the energy and transport infrastructure available at the time will determine the outcome.

The third largest in the world the Indian railway system with a track of over 66,030 kilometres. Freight volumes stand at number four globally. Out of the transported coal 90 percent which is equal to 50 percent of India's electrical power, is moved by rail. The strategy of the Indian railway is to raise the average speed on important tracks using conventional technology and, at the same time, upgrade some major connections by introducing state-of-the-art high-speed technologies.

A Russian-Indian oil or gas pipeline is another infrastructure project far off in the future. Geography and politics are both in the way for the time being. The route would possibly cross either Afghanistan which is conflict ridden and India's arch rival Pakistan, or the vast mountainous tracts of inner China. A memorandum of understanding has already been signed by Gazprom with Engineers India to conduct joint studies for a direct pipeline connection, a North-South Eurasian pipeline from Siberia to the Indian subcontinent might take decades to materialise ${ }^{10}$. 
The multimodal route connecting China, Kazakhstan, Azerbaijan, Georgia, and Turkey, and finally reaching Europe is the Trans-Caspian International Transport Route which is $4,766 \mathrm{kms}$ long. This corridor that comprises $4,256 \mathrm{~km}$ by rail and $508 \mathrm{~km}$ by sea. A cargo train launched from China will be able to reach Europe with this route once connected with Baku-Tblisi-Kars railway. Azerbaijan, Georgia, and Turkey are connected through this project directly via rail links. There are certain disadvantages in this route that need to be addressed before this route becomes fully functional.

Across countries various regulations related to customs and railway tariffs exists in the route, which require cooperation to establish single tariffs and harmonised customs procedures. The links to be fixed which are the concerns the Baku-Tbilisi-Kars railway connection. The Baku to TurkeyGeorgia border railway connection is already completed and modernised. The tunnel of $4 \mathrm{kms}$ long that connects Georgia and Turkey has been constructed. The construction of a rail line in the Turkish part from the Turkey-Georgia border to Kars is the only left part which will help functioning of the railway connection of Turkey with the Caspian region. Once this section is completed, the transport route from China to Europe will be uninterrupted ${ }^{11}$.

It is expected that an estimated INSTC cargo capacity of 20-30 million tons goods per year to provide faster and more efficient trade connectivity between Europe and Southeast Asia. In 2014 a dry run was conducted on the route, from Mumbai to Baku and Astrakhan via Bandar Abbas. There 
will be 30 percent cheaper transport and transportation period will be 40 percent shorter than the existing routes as per the results obtained.

After the Chabahar Port, the INSTC will be second corridor for India which will give access resource rich Central Asia and its market. The Chabahar port in coupled with INSTC will be a game changer for India's strategic and economic goals in the Eurasian region. Besides Iran's Bandar Abbas port the Chabahar port could get linkages to the INSTC. The route would be connected with various other connectivity projects that the five Central Asian and other Eurasian countries have undertaken among themselves $^{12}$.

The ultimate goal of these efforts is to dismantle trade barriers among countries in the region, and in turn, invigorate intra-regional trade and investments. However, regional trade at the expense of global-integration does not help to increase global welfare. The economic integration not necessarily leads to a higher level of welfare unless it is not the one of natural trading partners as argued by analysts ${ }^{13}$.

Given emerging global production system in these days, the separation from global trade is costlier than before as it means the loss of opportunity to access the global value chains. The integration into global value chains requires efficient supply chains that involve transportation system without fragmentation. The transportation system efficiency encompasses not only physical infrastructure but also related institutions and practices ${ }^{14}$.

This issue has been raised particularly with respect to the economic integration of Eurasian region and Russia ${ }^{15}$. The highly diversified 
political, economic and cultural systems, Eurasia is an extreme vast region. Even among Russia and the former CIS countries, there exist a big difference in institutions and government practices $^{16}$.

\section{India and Its connectivity through INSTC}

After India decided to join international customs convention TIR following cabinet approval the implementation of the INSTC has moved closer. The modalities of INSTC were discussed in order to make functional at a multi-stakeholder meeting. Delhi is working on INSTC which is one of the corridors as part of connectivity initiatives parallel to China's One Belt One Road strategy.

In India the Federation of Freight Forwarders' Associations conducted a study which showed that INSTC will be $30 \%$ cheaper and $40 \%$ shorter than the existing routes. Iran Railways, Azerbaijan Railways and logistics company ADY Express and Russia's JSC RZD on October 2017, organised the first test shipment on the INSTC. On September 22 the train left Mumbai and arrived in Russia's Kaluga Region on October 12. The transit time was 23 days. At the moment maritime routes for freight transport is being used by Russia and India, with goods reaching their destination in about 40 days.

The shipped containers were sent to the Iranian port of Bandar Abbas from Mumbai, then transported by rail to Iran's Rasht station and from there delivered by road to Astara which is in Azerbaijan, reloaded on the railway and finally delivered to the destination in Russia. On the INSTC two routes dry runs were conducted in 2014, the first from Mumbai to Baku via 
Bandar Abbas and the second from Mumbai to Astrakhan via Bandar Abbas, Tehran and Bandar Anzali. Chabahar port in Iran once functional and connected to the Iranian Railway network will also be part of INSTC $^{17}$.

The region of Central Asia can be of significant interest to India, not least of all due to its large untapped reserves of natural reserves of hydrocarbons and minerals. Kazakhstan for example has the 11th highest oil reserve in the world ${ }^{18}$. This poses for India an interesting potential as the country lacks in natural reserves of its own and was therefore also the 4th largest importer of LNG in the world in $2013^{19}$. Besides Russia other powers such as China, the United States and the European Union have shown an increasing interest in the region with their own multilateral projects, leading some to speak about a revival of the 'great game' that occurred in the 19th century between the Russian and British empires ${ }^{20}$.

For both India and CARs energy is a major motivation to cooperate, as it is in the interest of CARs to diversify their economies in this way and in multilateral co-operations. A rare example on this scale is the role of Indian state-owned company ONGC (Oil and Natural Gas Commission), which took over a company with stakes in oil fields and a part of an exploration opportunity around the Caspian $\mathrm{Sea}^{21}$. The same company in 1997 had acquired the right to drill exploratory for 5 years in another region in Kazakhstan. This company had also invested in a region in Turkmenistan, but as noted above it turned out that there was not enough potential at that $\operatorname{site}^{22}$. 
In 2015 exploratory drilling began in the region around the Caspian Sea, but with mixed results. In another project in which ONGC was involved, the stakes given to the company were taken away and given to a Chinese company by the Kazakh government. While there can be several reasons for this, it is perhaps telling that the ONGC turned away another offer of a stake in an oilfield by the Kazakh government. India to engage in such projects lack operational power or some unwillingness as it may point, next to the possibility that the Chinese offered more money. More reasons provided for this difference is that China shares a border with several of the CARs, among which is Kazakhstan ${ }^{23}$.

The economy of China is considerably bigger than India's, with a GDP of US \$21.27 trillion compared to India's GDP of US \$8.721 trillion in 2016. The Chinese government acquire more options with this, although a related analysis is being provided by Lee \& Gill. The Indian economy due to several market reforms as argued is controlled mostly by the private sector and given the relatively small presence of the government in the economy, its state-owned enterprises which cannot be provided by it is charged with investing in overseas resources with the same level of cheap capital that is available to Chinese state-owned enterprises. The economy of India is consumption driven rather than an export-led one unlike that of China, and the private sector has less risky opportunities to invest at home or elsewhere around the world than those offered in Central Asian states ${ }^{24}$.

To develop its relations with the energy rich region of Central Asia, India has now started to think in ways which would give boost to its foreign policy on various aspects. There are many difficulties such as the presence 
of great powers in the region, limited trade and limited size of markets, for more than a decade Central Asia has gained valuable place in Indian foreign policy affairs. The Connect Central Asia Policy is the growing interest of this concrete indication, which is based on pro-active political economic and people to people connectivity with the region both individually and collectively.

Another side of the Central Asian coin are the increasing role of big powers to make their influence felt in the region. There have been attempts to explore in these contexts that how far geo-political calculation is a factor in India's new policy 'Connect Central Asia' and its implications for India. The evolving relations with the region having common interests on many issues in South and Central Asia from geopolitical, geo-economic and geostrategic perspectives has been explored in the recent past ${ }^{25}$.

It is a fact the big challenge in itself is the importance of Central Asia and there are several drawbacks in speeding up the relationships and governmental interactions of India with the region under the present circumstances. The South and Central Asia in its present settings seems to be very difficult to bring energy directly and easily from the region.

In order to establish connectivity with Central Asia to satisfy its energy needs in particular India is faced with some of the challenges as it lacks any direct land route. In establishing easy and sustainable connection this forms the challenge fundamentally. It is for India's trade with Central Asia that it poses a great challenge as it has to seek other options to connect with Central Asia. Land route connection plays a key role in developing trade and transport of energy materials ${ }^{26}$. 
The weak border is the main geopolitical challenge for India and associated problems. The hostility of neighbours like Pakistan and China with India. China's encircling India via Nepal, Bangladesh, Sri Lanka and Pakistan poses problems for its security. The deteriorating relations with neighbours and the effect of weak borders such as Pakistan's excursion and infiltrating of militant into Kashmir, pressures of migration from Bangladesh, Tamils' identity in Sri Lanka and Nepal's open borders with illegal trade in many points which made India an isolated land which has to struggle for making presence across the region.

It is for the projects like the TAPI (Turkmenistan, Afghanistan, Pakistan, India) pipeline that these conditions are the major challenges as Indian government apprehends that relations with neighbours would jeopardize its energy security. The present political situation of Afghanistan is an added problem which is not conducive to this project ${ }^{27}$.

India's gateway to expand trade and investment links with CAR nations and Eurasia will be INSTC. Indian goods to Russia and Central Asia currently move either via Rotterdam through sea or to St. Petersburg or from the port of Qingdao in China that takes over 50 days because of the absence of surface transport connectivity. Consequentially, India's trade volume with Central Asia is less than US \$ 1 billion, which pales in comparison to Russia (US \$ 30 billion) and China (US \$ 50 billion), both of them have a shorter axis of transport.

To take shape only recently a gap of seventeen years has been dragged by the INSTC. The delay is primarily attributable to two major factors. First, Iran which is a major hub in this corridor got isolated globally and was 
confronted with sanctions on the pretext of developing nuclear arsenal. The corridor of this transport secondly includes various subprojects requiring bilateral and multilateral agreements, apart from funding issues which mired the project. Unlike the BRI, where China is doing the bulk of heavy lifting and herding the project. The two large players, Russia and India were reluctant to shoulder the responsibility for shaping and guiding the progress.

None of the participant countries had deep pockets to push the project which resulted in scarce supply of fruition funding the first requirement for such project. Central Asia's energy abundance, changing geopolitics, tremendous shrill created by the BRI acted as tailwind for INSTC. A lot of progress has been witnessed in the past few years. Surprisingly, India has emerged as a pathfinder and has orchestrated synchronous acts to take the Corridor to its logical shape and direction ${ }^{28}$.

\section{CONCLUSION}

Strides towards achieving a new framework is being made by the INSTC. To incorporate other interested states, including countries of the Caucasus, Central Asia, and Eastern Europe, and perhaps also Oman this project has the potentiality. History has been the witness to the difficulties in transport projects. Once an important strategic and economic project, the TransSiberian Railway now moves only about 10,000 containers per year mainly due to a lack of service reliability. The potential for militarization of the Caspian, are the threats strategically and politically. The danger that the route be abused for illicit drug and weapons trafficking have already 
been noted by Russian politicians, following existing routes from Afghanistan in the south via Central Asia into Russia and Europe.

Expanding trade volumes between INSTC members the importance of which is taken into account, fast-tracking the India-Eurasian Economic Union (EAEU) Free Trade Agreement would be a crucial step. It will allow for the use of all the connectivity infrastructure and mechanisms currently in the region besides increase in overall trade, justifying increased focus and investment from the government alongside the private sectors. Improved visa facilitation for the region's businessmen and investors in the medium-term should also be looked into.

To benefit from the advantages that INSTC provides, member countries need to coordinate their efforts. About participating in the corridor for which both Russia and India have been enthusiastic and partnership with Iran. India is Iran's key partner in developing Chabahar Port and coordinated the INSTC friendship rally. Russia is also seeking to utilize INSTC instead of the traditional Suez Canal route. A special centre has been established in Russia's ministry of transport to coordinate transport and logistics with Iran's ministry of roads and urban development. Azerbaijan is also contributing to the development of Rasht-Astara railroad, which will help fix the missing links of the corridor.

There are certain challenges that need to be addressed in INSTC. A comprehensive approach is required; one that is not solely focused on infrastructure and transport but on added value, competitiveness and development. Agreements about customs and fees should also be competitive and include the private sector and traders. Additionally, 
awareness about competing in an international market should be established, especially in Iran where this gets overshadowed by the country's geopolitical advantages. International sanctions are also a significant challenge that needs to be addressed.

It needs to be truly transcontinental corridor for the INSTC, if it is to attain economic viability. Its physically connection with a greater number of countries in Europe is what it means, extending its reach beyond the present termination point of St. Petersburg in Russia and expanding towards the North along with the Western direction to get more integrated with European rail networks. There have been high-level discussions in recent months about stretching the corridor further to include countries such as Latvia, Estonia and Finland. This is taking place at a relatively slow pace and mostly on bilateral or trilateral terms, featuring two of the Nordic and Baltic states and then principally Russia, Iran, Azerbaijan, India and Afghanistan. In conjunction with the European Union (EU) the Baltic and Nordic regions are already collaborating on significant transport initiatives, it might be worth exploring that the European Union backed projects are often integrated with the INSTC.

The break in the connectivity of inland transportation and limited access to sea ports would inhibit Eurasian countries, in particular the countries of Central Asia, from efficiently managing regional supply chain and in turn, participating in the global value chain. Expansion of intra-regional connectivity requires improvements in cross-board infrastructure in terms of quantity and quality. The possible measures that should be accompanied includes upgrading TCR (Trans China Railway) and TSR (Trans-Siberian 
Railway), improving logistics facilities, streamlining customs procedures, harmonizing institution and standard such as customs documents and rail gauge and building capacity of logistics system management, and so on. These physical and institutional improvements, however, need large-scale and high-risk investments. That is why strategic investment plans are required. To investigate the impact of connectivity improvements on Eurasian economic integration it is essential works to this end.

On several fronts like anti-terrorism agenda, smuggling, economic development, pipeline geopolitics, education improvement, econnectivity, land reform project, hospital, fraternity, religious understandings on which Central Asia and India need to join hands and which are needed to be addressed carefully. In connectivity with the Central Asia under the present geopolitical realities there are difficulties which are being realised practically, India should adopt pragmatic strategies and should continue its political dialogues with CARs and other transit countries. The best strategy which suit its interests is that of cooperation and not that of the competition or confrontation. India needs to pursue its 'Connect Central Asia Policy' energetically, irrespective of its unimpressive gains so far, to achieve plausible breakthroughs in regional, economic, trade and energy cooperation with new states. The policy can play a role of anchor in increasing India's hard and large period planned attention in view of its further relations with Central Asia. 


\section{REFERENCES}

[1.]Regine A. Spector, The North-South Transport Corridor, Brookings Institute, July 3, 2002.

[2.] Sandeep Singh and Amanpreet Kaur, "Connect Central Asia Policy"e Factor in India's Soft Power Initiatives in CARs: Problems and Prospects", International Journal of Advanced Research in Management and Social Sciences, vol 3(12), 2014.

[3.] Roy, Meena Singh, "International North-South Transport Corridor: Re-energising India's Gateway to Eurasia”, IDSA issue brief, 18 august 2015.

[4.]Roshan Iyer, Filling In the North-South Trade Corridor's Missing Links, The Diplomat, February 28, 2018.

[5.] Ritika Passi, Money matters: Discussing the economics of the INSTC, ORF Observer Research Foundation, Occasional Papers, $20^{\text {th }}$ April, 2017.

[6.] "Iran-Azerbaijan Rail Linkup in a Month," Financial Tribune, January 15, 2017, https:/financialtribune.com/articles/economy-business-andmarkets/57451/iran-azerbaijan-rail-linkup-in-a-month;

Nigar Abbasova, "Date set for commissioning of Astara-Astara railway," $\begin{array}{llll}\text { AzerNews, } & \text { February } & \text { 2017, }\end{array}$ http://www.azernews.az/business/108582.html.

[7.] International North-South Transport Corridor (INSTC), https://www.clearias.com/international-north-south-transportcorridor-instc/. 
[8.]INSTC: Iran's Role and Future Development, Ministry of Roads \& Urban Development Islamic Republic of Iran, 31 July 2018.

[9.]Hriday Sarma and Dwayne R Menezes, The International North-South Transport Corridor (INSTC): India's grand plan for northern connectivity, SADF South Asian Democratic Forum, 8 June, 2018.

[10.] Thomas Fasbender, Integrating Eurasia: Evolving Russian-Indian infrastructure links, DOC (Dialogue of Civilisation) Research Institute, Germany, August 15, 2017.

[11.] Hazar Strategy Institute (2015), 'Trans Caspian Rail Corridor to Transform Europe-China Trade', http://www.hazar.org/blogdetail/blog/trans_caspian_rail_corridor_to_ transform_europe_china_trade_1348.aspx?currentCulture=en-US (accessed 27 August 2015).

[12.] North-South corridor 'vital link' between Iran, Russia, CIS nations - Indian official, Azernews, December 272018.

[13.] Wonnacott and Lutz, 1989; Summers, 1991; Krugman, 1993.

[14.] Arvis and Sheperd, 2013.

[15.] Obydenkova, 2011.

[16.] Atik, 2014.

[17.] Dipanjan Roy Chaudhury, International North South Transportation Corridor for better Indo-Russian connectivity inches towards reality, The Economic Times, Jul 12, 2018.

[18.] Lee \& Gill 2015, 112.

[19.] Kulkarni \& Nathan 2016, 183.

[20.] Adnan \& Fatima 2015, 188.

[21.] Lee \& Gill 2015, 113; Kavalski 2012, 101. 
[22.] Kulkarni \& Nathan 2016, 188.

[23.] Stobdan 2016, 17.

[24.] Lee \& Gill 2015, 113.

[25.] Sandeep Singh, Connect Central Asia Policy, Factors in India's Soft Power Initiatives in Central Asian States: Problems and Prospects, Research Gates, December 2014.

[26.] Foshko 2012: 8.

[27.] Jacob 2005: 311.

[28.] Kunal Kashyap, Instc-India Breaches: The Great Wall of Pakistan, Centre for Land Warfare Studies, May, 2018.

\section{Bibiliography}

Balooch M (2009) Iran and India's cooperation in Central Asia. Central Asia Caucasus institute and Silk Road studies program. China and Eurasia forum quarterly $7: 25-29$.

Bavar F (2010) Studying Chabahar commercial- industrial free zone map focusing on developing urban development.

Behuria A, Rizvi M (2015) India's renewed interest in Chabahar: Need to stay the course. Institute for defence studies and analysis.

Campbell I (2013) India's role and interests in Central Asia. Saferworld.

CAREC (Central Asia Regional Cooperation).2009. "Transport and Trade Facilitation: Partnership for Prosperity." Available from http://www.adb.org/documents/reports/CARECTranspo-TradeFacilitation/CAREC-Transpo-Trade-Facilitation.pdf, Accessed 16.02.2011. 
Costas, Alexopoulos. 2010. "Comparison study of maritime and rail transport along the Euro-Asia transport linkages", UNECE / Transport division. Available from http://www.unece.org/trans/main/wp5/wp5_ge2_05.html Accessed 14.02.2011.

Dollar, D. 2017. "Is China's Development Finance a Challenge to the International Order?" The Brookings Institutions: The New Geopolitics of Asia, Accessed November 9, 2017. https://www.brookings.edu/wpcontent/uploads/2017/11/fp_20171109_china_development_finance.pdf.

Dreher, A., A. Fuchs, B. Parks, A. M. Strange, and M. J. Tierney. 2017. “Aid, China, and Growth: Evidence from a New Global Development Finance Dataset." AidData Working Paper, no. 46, Accessed October 10, 2017. http://docs.aiddata.org/ad4/pdfs/WPS46_Aid_China_and_Growth.pdf.

Enright, M. Developing China: The Remarkable Impact of Foreign Direct Investment. Abingdon: Routledge, 2017.

European Union. TRACECA Programme. International Logistics Centres/Nodes Network in Central Asia at the Republic of Kazakhstan, Kyrgyz Republic, Republic of Tajikistan, Republic of Uzbekistan and the Republic of Turkmenistan EuropeAid/125727/C/SER/MultiTask A Report - Kazakhstan, September 2009.

Guo, J. P. 2018. "Goujian Renlei Mingyun Gongtongti De Weida Shixian: Xie Zai Xi Jingping Zhuxi Tichu 'Yidaiyilu' Changyi Wu Zhounian.” [The Great Practice of Building a Community of Shared Future for Mankind: Writing the Fifth Anniversary of President Xi Jinping's Proposal for the "Belt and Road Initiative".] Renminwang, October 4. doi:10.3168/jds.2017-14085.

Guojia Fazhan he Gaige Weiyuanhui, Waijiaobu, Shangwubu. 2015. "Tuidong Gongjian Sichouzhilu Jingjidai He 21 Shiji Haishang Sichouzhilude Yuanjing 
Yu Xingdong." [Vision and Action on Promotion of Building the Silk Road Economic Zone and 21st Century Maritime Silk Road.] Accessed March 28, 2015. http://www.ndrc.gov.cn/gzdt/201503/t20150328_669091.html.

Guowuyuan. 2015. “Guanyu Tuijin Guoji Channeng He Zhuanbei Zhizao Hezuo De Zhidao Yijian.” [Guiding Opinions of Promoting International Industrial Capacity ·And Equipment Manufacturing Cooperation.] Accessed May 13, 2015. http://www.gov.cn/zhengce/content/2015-05/16/content_9771.htm.

Karimikia A and Moqadam M (2012) Studying the attraction factors for investment in Arvand free zone. Economic journal. Study of economic problems and policies magazine. No. 6,7 .

Mirzadeh A, Pad M, Salarzehi H, Abtin A (2014) Identification and prioritizing the investment opportunities in Chabahar free zone using analytical hierarchy:

Opportunities in Chabahar free zone using analytical hierarchy. International Journal of Academic Research in Business and Social Sciences 4: 320-330.

Sial S (2016) The China-Pakistan economic corridor: An assessment of potential threats and constraints.

Zafar A (2015) India-Central Asia: Finding new synergies for greater engagement. Indian council of world affairs. 